\title{
Revitalizing Traditional Culinary In Supporting Sustainable Tourism Viewed From Culinary Linguistics
}

\author{
Ni Wayan Kasni, I Wayan Budiarta \\ \{info@warmadewa.ac.id\} \\ Universitas Warmadewa, Denpasar, Bali
}

\begin{abstract}
Bali is a province whose economy depends on tourism. According to Sudibya (2019) $2 / 3 \%$ of the economy is based on tourism. Referring to the statement, it is deemed necessary for new innovations in the development of tourism in Bali. One of them is a traditional culinary tour where the ingredients are from agricultural or plantation products which are indeed the hallmark of Balinese products as they come to Bali are not only to see view and culture, they also want to try local food. Every region in Bali has its own uniqueness in relation with culinary. Based on this reason,this research was done to investigate the lexicons of traditional culinary as a way to revitalize it in tourism sector. Besides, it is also aimed at showing the proverbs. The theory applied was Culinary Linguistics defining that culinary linguistics is qualitative study of language in food traditions or eating habits through the linguistic paradigm (Jabonillo, 2016: 18). Based on the research done, it is found that words used in traditional culinary can be grouped into 5 (five), such as local fruit, vegetable, fish and meat, tubers, and grain. In general the traditional ways to cook are steaming, grilling, frying, boil, burning with covering in embers, roasting. In communication the people tends to use something surrounding their lives which is conveyed in the form of proverbs.
\end{abstract}

Keywords: culinary linguistics, traditional culinary, sustainable tourism, revitalizing.

\section{Introduction}

Bali is well known as tourism destination. It has unique culture, good view, and many tourist attractions. As a tourist destination, it should be completed with tourism facilities, such as accommodation, human resources, travel agencies, restaurants, and many other things which are related with tourism. All of them are all for making the tourist feel enjoyable coming to Bali. To make the sustainable tourism in Bali, the government has planned and built new tourist destination, namely building agrotourism, and building new tourist destinations almost in every region in Bali, such as Edelweis garden in Karangasem, spiritual tourism in Sangeh, agrotourism in Petang, Blossom Garden in Tabanan, Alam Tirta in Samuan. Those new tourist destinations are all to offer many choices if they come to Bali. 
There are many ways that can be done to make the tourism sustainable in Bali. One of them is making innovation in tourism field, namely revitalizing the traditional culinary in Bali as the reason that the tourists coming to Bali are not only for enjoying the view, culture, attraction, but they also need to know our traditional food. The existence of traditional food must be revitalized. The previous researches done were only focused on the potency of culinary ${ }^{[2]}$, the role of culinary tourism in improving the image of tourist destinations ${ }^{[3]}$, the exploration of culinary tourism in developing tourism ${ }^{[4]}$, the investigation of typical food in Semarang as an inventory assets and tourism promotion ${ }^{[5]}$, the importance comparative characteristics analysis for creative industrial entrepreneur in culinary and non culinary field [6]. All of those researches did not apply linguistics theory. The previous researches used linguistics theory are only a few researches on culinary using linguistics theory, such as semantic analysis and Hebrew cooking terms ${ }^{[7]}$, traditional food in the perspective of culinary linguistics ${ }^{[8]}$, and Coffee as Geo Product for Geo Tourism based on sustainable agricultural practice concept ${ }^{[9]}$. These researches were only discussing the cooking terms and traditional culinary in general. They didn't observed deeply the name of the traditional foods, the verbs or the process, and the proverbs related with the ingredients used in traditional food. That's way this research is focused on traditional culinary viewed from culinary linguistics. It is aimed at finding the words related with traditional culinary and their meaning and the proverbs the people usually which are related with the ingredients of the food.

\section{Method}

This research is categorized as qualitative one. The data used were spoken data and written data. The spoken data are the data about the processes or verbs in traditional culinary, some of traditional ingredients which are almost endangered, and the proverbs which were collected through interviewing the informants. Then they were transcribed in written data. The written data are about name of food which are still available in the region, and the processes. Besides, this research also used documentary method which was applied in taking the pictures of the restaurant selling traditional food and the traditional menu the serve in the restaurants. The analysis was a descriptive analysis using theory of linguistics culinary by Jabonillo 2016 and the theory of Gerhardt (2013).

\section{Result and Discussion}

As a tourism destination, traditional food can be used as a region identity, for instance Klungkung in the eastern part of Bali is famous for serombotan, Gianyar is famous for Bali Guling Gianyar, Singaraja is famous for Siobak, and the like. The lexicons presented below are from the northern part of Badung Regency. (Gerhardt, 2013) stated that the field of culinary linguistics that are (1) comparative linguistics (2) morphology and word formation (3) syntax and grammar (4) word and meaning (5) spoken discourse (6) food writing.

Based on the scope of discussion, it will be discussed the words/ lexicons relating with traditional culinary and their meaning.

a. The ingredients of traditional culinary

The ingredients of traditional culinary is grouped into 5 (five), namely (1) name of local fruit, (2) meat and fish, (3) tubers, (4) vegetable, (5) grain. 
Table 1. Name of local food

\begin{tabular}{|c|c|c|c|c|}
\hline Bali & Indo & Latin & Inggris & $\begin{array}{l}\text { Result of } \\
\text { cooking/the process }\end{array}$ \\
\hline Sukun & Sukun & dentibus gum & breadfruit & $\begin{array}{l}\text { Steam cake, } \\
\text { crackers }\end{array}$ \\
\hline manggis & manggis & mangosteen & mangosteen & juice \\
\hline kepundung & kepundung & Baccaurea racemosa & kepundung & Fruit salad \\
\hline teep & terap & Artocarpus & Tarap fruit & Roasted tarap \\
\hline Buah buni & Buah buni & baca & Baca & Fruit salad \\
\hline duren & durian & durian & Durian & Juice, cake \\
\hline wani & wani & Mangifera caesia Jack & Wani fruit & juice \\
\hline pakel & pakel & $\begin{array}{l}\text { (Mangifera foetida } \\
\text { Lour. }\end{array}$ & Pakel fruit & Fruit salad \\
\hline buluan & rambutan & rambutan & Hairy fruit & Fruit salad \\
\hline sentul & kecapi & Sandoricum koetjape & lute & Fruit salad \\
\hline Mundeh & mundu & Garcinia dulcis & Mundu fruit & Fruit salad \\
\hline ceroring & duku & Lansium domesticum & $\begin{array}{l}\text { Ceroring } \\
\text { fruit }\end{array}$ & Fruit salad \\
\hline utu & utu & $\begin{array}{l}\text { Parartocarpus venenosa } \\
\text { Becc }\end{array}$ & Utu fruit & Fruit salad \\
\hline cereme & cerme & Phyllanthus acidus & Cermai fruit & Fruit salad, candy \\
\hline blimbing & blimbing & blimbing & Star fruit & Fruit salad \\
\hline Blimbing buluh & $\begin{array}{l}\text { Blimbing } \\
\text { wuluh }\end{array}$ & Averrhoa bilimbi & Star fruit & $\begin{array}{l}\text { Mixed with fish } \\
\text { soup }\end{array}$ \\
\hline muntis & Jeruk muntis & citrus grandis & Muntis fruit & Fruit salad \\
\hline apokat & alpokat & avocado & avocado & Fruid salad, juice \\
\hline waluh & Labu kuning & Cucurbita moschata & pumpkin & $\begin{array}{l}\text { Steam cake, soup, } \\
\text { crackers }\end{array}$ \\
\hline Waluh gepang & Labu siam & Sechium edule & chayote & Soup, vegetable \\
\hline
\end{tabular}

Table 2 meat and fish

\begin{tabular}{|c|c|c|c|c|}
\hline Bali & Indo & Latin & Inggris & The result of cooking \\
\hline lindung & belut & eel & eel & $\begin{array}{l}\text { Fried eel, copped eel wrap with } \\
\text { coconut leaf }\end{array}$ \\
\hline mujair & mujair & $\begin{array}{l}\text { Oreochromis } \\
\text { mossambicus }\end{array}$ & $\begin{array}{l}\text { Mozambique } \\
\text { tilapia, }\end{array}$ & $\begin{array}{l}\text { Sauted Mozambique tilapia, soup, } \\
\text { fried }\end{array}$ \\
\hline lele & lele & silurus & catfish & $\begin{array}{l}\text { Fried, soup, copped catfish wrap } \\
\text { with coconut fish }\end{array}$ \\
\hline Kebo & kerbau & Bubalus bubalis & buffalo & Copped meat, soup, satay \\
\hline sampi & sapi & vitula eligans & cow & Copped meat, soup, satay \\
\hline celeng & bali & cetis porci & pig & Copped meat, soup, satay \\
\hline kakul & Keong sawah & Pila ampullacea & Rice conch & $\begin{array}{l}\text { Satay, soup, copped and wrapped } \\
\text { with coconut leaf }\end{array}$ \\
\hline nyawan & & & & \\
\hline
\end{tabular}


Table 3. Name of tubers

\begin{tabular}{|c|c|c|c|c|}
\hline Bali & Indo & Latin & Inggris & \\
\hline keladi & keladi & Colocasia esculenta & & Boiled taro, crackers \\
\hline sela & Ketela rambat & Ipomoea batatas & $\begin{array}{l}\text { taro } \\
\text { Sweet potato }\end{array}$ & Boiled potato, crackers \\
\hline $\begin{array}{l}\text { Sela sawi } \\
\text { sueg } \\
\text { sekapa }\end{array}$ & $\begin{array}{l}\text { Ketela pohon } \\
\text { suweg } \\
\text { Umbi gadung }\end{array}$ & $\begin{array}{l}\text { Manihot utilissima } \\
\text { Amorphophallus } \\
\text { Dioscorea hispida Denust }\end{array}$ & $\begin{array}{l}\text { cassava } \\
\text { suweg }\end{array}$ & $\begin{array}{l}\text { Boiled cassava, crackers } \\
\text { Steamed suwed, crackers } \\
\text { Steamed umbi gabung }\end{array}$ \\
\hline
\end{tabular}

Table 4. Name of vegetable

\begin{tabular}{|c|c|c|c|c|}
\hline Bali & Indo & Latin & Inggris & \\
\hline buangit & buangit & & $\begin{array}{l}\text { wild edible spider } \\
\text { flower plants }\end{array}$ & Soup, vegetable \\
\hline kesegseg & krokot & Portulacaceae & purslane & vegetable \\
\hline Don gedang & Daun pepaya & 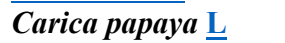 & Papaya leaf & vegetable \\
\hline $\begin{array}{l}\text { Don } \\
\text { belimbing }\end{array}$ & Daun belimbing & A. carambola & Star fruit leaf & $\begin{array}{l}\text { Vegetable, mixed } \\
\text { with copped meat }\end{array}$ \\
\hline embung & $\begin{array}{l}\text { Rebung/tunas } \\
\text { bamboo }\end{array}$ & Bambuseae & Bamboo shoots & Vegetable, soup \\
\hline $\begin{array}{l}\text { Gedang } \\
\text { nguda }\end{array}$ & Pepaya Muda & Carica papaya $\underline{\mathrm{L}}$ & Young papaya & $\begin{array}{l}\text { Soup, mixed with } \\
\text { copped }\end{array}$ \\
\hline kelor & kelor & Moringa oleifera & moringa & vegetable \\
\hline Punyan biu & Batang pisang & musa & $\begin{array}{l}\text { the stem of } \\
\text { banana }\end{array}$ & vegetable \\
\hline Pusuh & Bunga pisang & musa & $\begin{array}{l}\text { The flower of } \\
\text { banana plant }\end{array}$ & vegetable \\
\hline Don tuwi & Daun turi & Sesbania grandiflora & Turi leaf & vegetable \\
\hline Don ubi & $\begin{array}{l}\text { Daun ketela } \\
\text { pohon }\end{array}$ & Manihot utilissima & Cassava leaf & vegetable \\
\hline $\begin{array}{l}\text { Muncuk } \\
\text { waluh }\end{array}$ & $\begin{array}{l}\text { Pucuk labu } \\
\text { kuning }\end{array}$ & Cucurbita & $\begin{array}{l}\text { The shoots of } \\
\text { cassava }\end{array}$ & vegetable \\
\hline $\begin{array}{l}\text { Muncuk } \\
\text { jepang }\end{array}$ & Pucuk labu siam & Sechium edule & chayote & vegetable \\
\hline $\begin{array}{l}\text { Muncuk } \\
\text { don sela }\end{array}$ & $\begin{array}{l}\text { Pucuk daun } \\
\text { ketela rambat }\end{array}$ & Ipomoea batatas $\mathrm{L}$ & $\begin{array}{l}\text { The shoots of } \\
\text { sweet potato }\end{array}$ & vegetable \\
\hline nangka & nangka & $\begin{array}{l}\text { Artocarpus } \\
\text { heterophyllus }\end{array}$ & jackfruit & $\begin{array}{l}\text { Vegetable, mixed } \\
\text { with copped meat }\end{array}$ \\
\hline timbul & timbul & Artocarpus altilis & Timbul vegetable & vegetable \\
\hline
\end{tabular}

Table 5 name of grain

\begin{tabular}{|c|c|c|c|c|}
\hline Bali & Indo & Latin & Inggris & \\
\hline Baas & beras & Oryza sativa $\mathrm{L}$ & rice & $\begin{array}{l}\text { Porridge, rice, } \\
\text { cake }\end{array}$ \\
\hline Ketan & ketan & Oryza glutinosa & White rice & Cake, crackers \\
\hline Baas barak & Beras merah & oryza glaberrima & Red rice & $\begin{array}{l}\text { Cake, porridge, } \\
\text { crackers }\end{array}$ \\
\hline Injin & Beras hitam & oryza sativa L. & Beras hitam & Cake \\
\hline
\end{tabular}




\begin{tabular}{|c|c|c|c|c|}
\hline Bali & Indo & Latin & Inggris & \\
\hline $\begin{array}{l}\text { kedele } \\
\text { Jagung }\end{array}$ & $\begin{array}{l}\text { kedelai } \\
\text { Jagung }\end{array}$ & $\begin{array}{l}\text { Indica } \\
\text { Glycine soja } \\
\text { Zea mays ssp. } \\
\text { mays }\end{array}$ & $\begin{array}{l}\text { Soya beans } \\
\text { corn }\end{array}$ & $\begin{array}{l}\text { Cake, vegetable } \\
\text { Soup, cake }\end{array}$ \\
\hline
\end{tabular}

The cooking terms used in Traditional Balinese culinary

If we look at the way of cooking the traditional food in Bali, each of them has its own way of cooking, so the cooking terms will be different from one food with another food. The more the variants of the ingredients which produce traditional food, the more the cooking terms they have. The discussion below is described the cooking term in traditional Balinese food.

1. Lablab 'boil' This cooking term is used for making simple food, such as those which are from tubers, namely cassava, sweet potato, taro; from grain for examples: soya beans, corn. Besides for making simple food, this process is usually done for vegetable before it is made into their variants.

2. Ngukus 'steam' This term is done for the ingredients derived from tubers and grain. It is another choice of simple cooking for making simple food. Instead of just simply steaming the ingredients on the steamer in Bali is called kukusan and use dangdang ' a kind of pan', the food which is usually wrapped with coconut leaf which is called pepesan and Balinese cake called sumping.

3. Ngoreng 'frying' It refers to the way of cooking using oil. It is done on making crackers, fish.

4. Ngetep 'cut' This process is done before the ingredients are cooked.

5. Ngepik 'picking of the top of the ingredients' It is also done before the process of cooking, but it is only for the ingredients which are derived from the shoots of the plants.

6. Ngelasin 'peeling' This process is done before the ingredients are cooked and they are only for the ingredients that need that process.

7. Ngaru' soaking the medium cooked rice before it becomes well done cooked rice' This is only done for the ingredients from grain like rice.

8. Ngiris 'making into small slices' This cooking term is used for making the ingredients thin. It is done for meat, cassava, sweet potato, pumpkin, fish.

9. Nyisir 'making into something into the thinnest' This is usually for making the brown sugar thin so, it is easy to be well done.

10. Mejek 'pressing the ingredients to make it smooth' This process is before cooking and it is done for the ingredients from leafs, flour and meat.

11. Mulung 'making the dough like ball' This cooking term is for cooking cake from cassava, sweet potato, fish, and meat.

12. meres 'sequezing' This cooking term is used for making coconut milk, making lawar in which the ingredients are jack fruit, papaya, chayote, and making traditional drink called loloh.

13. Ngulig 'making the ingredients soft and mixing using stone' This process is done for making Balinese seasoning which contain union, garlic, ginger, turmeric, pepper, and the like based on the food that will be cooked.

14. Nunu ' cooking the food over the fire' This process is done for the ingredients which are from coconut, cassava, sweet potato, fish, meat.

15. Ngerajang ' chop the ingredients into small slices' It is only done for the seasoning, such as union, garlic, ginger, turmeric. 
16. ngintuk' mashing using stick' This term is also used for seasoning. This is another way of making the spices soft instead of cooking. It is done if the quantity of the spices is too much.

17. nambus ' burning the food by covering with live coals. It is done for cooking cassava, and sweet potato.

18. Mungkus 'wrapping with banana leaf' The process of mungkus is the process which is done before the food is cooking. It is done in making cake called sumping, fish or meat called pepesan. This process is continued with the process of steaming of grilling

19. Nyatnyat 'cooking with little oil and water' This is done for cooking meat or fish. The result of the process is the food look wet but not oily.

20. Nektek 'cutting meat until soft' This process is done for meat and done before cooking. The result is called ketekan 'chop meat'.

21. ngurab ' mixing the boiled ingredients with grated coconut. It is done for making traditional vegetable, cassava, suweg, sweet potato, taro.

22. nusuk 'skewers' The process is done on making satay whether is fish satay of meat satay.

23. Ngelilit ' wrapping around' The process of ngelilit is only done for making satay. Before it is cooked, the dough is wrapped around a small stick using hands.

24. Ngebet 'cooking satay by using traditional fan' The traditional way for grilling the satay is using traditional fan. It is hope that the live coals is good by flicking of the carchoal.

25. Nyakcak 'mashing using stone' This process is done for making the spices soft but the process is done using stone by hitting the scipes many times until it is soft.

26. ngerames 'cutting the skin of beef, pork' This process is only done in making lawar. The skin of the meat is cut into small slices.

27. ngaduk 'mixing' The process of mixing can be done for making the dough or during the process of cooking to make all the ingredients cook well or to make a good dough.

Naming System in Traditional Balinese Culinary

The system of giving name in Traditional Balinese culinary is various. It is not only for naming the food but it is also for naming the place where the food is sold. The naming system can be based on the ingredients of the food, the way to cook, or the owner of the stall. It can be seen in the discussion below.

Naming System Based on The Ingredients of The Food

a. Lawar kuwir 'chopped meat from kuwir'

b. Lawar Klungah 'choppep meat from the meat of young coconut'

c. Lawar kebo 'chopped meat from buffalo meat'

d. Sate kakul 'the satay from rice conch'

e. Jukut kelor 'the vegetable from moringa'

f. nasi sela 'the rice mixed with sweet potato'

The examples a-f show that they are the food which are made from the modifier of the NP like, kuwir, klungah, kebo, kakul, kelor, and sela.

Naming System Based on The Way of Cooking

a. Mujair nyatyat' sauted tilapia fish

b. Sate lilit 'wrapped around satay'

c. Mujair goreng 'ried tilapia fish

d. sela metambus 'sweet potato burned by covering with life coals'

The examples a-d show that the modifier of the NP,such as lilit, goring,lilit, metambus show the way of cooking. 
Naming System Based on The Owner of The Stall

a. Warung Men Wenci

b. Warung Men Sono

c. Sate Pan Bledor

The examples a-c show that Men Weni, Men Sono, Pan Bledor are name of preson. Therefore they show the owner of the stall.

The Proverbs Related with Food

In Balinese life, the language used is closely related with their environment. The lexicons they choose are also related with the plant, food that are available in their place. Here are some examples of Balinese Proverbs related with the ingredients of the food.

a. Ia cara kepundung tuh

b. Ia cara celeng

c. Ia mula demen mecik manggis 'He actually likes smashing the mangosteen with two hands

d. Nyonyonne care blego 'Her breast is like blego'

e. Be bebek be guling 'Duck meat, sukling pig'

In example (a) the proverb convey the meaning that from the outside she looks bad but actually inside she is good. The proverbs in example (b) is usually used for a lazy person. It is expressing the negative meaning that he only likes sleeping after eating. The proverb of example (c) is also denoting negative meaning. It is used for someone who likes looking for attention or position by downgrading himself. In example (d) the proverb is usually used for female who does not good breast. The last example is actually like a rhymes which that after laughting, she is crying. It is usually intended to the kids who likes crying.

\section{Conclusion}

The result of discussion show that the lexicons related with traditional culinary are divided into 5 (five), namely local fruit, vegetable, tubers, fish and meat, and grain. The number lexicons of cooking process categorizing as verb are 25 verbs. Besides, in giving the name Balinese people have their own way to give the name of food and the stall selling traditional food.

\section{References}

[1] B. Sudibya, "Pengembangan Ekowisata Bali Peluang dan Tantangan," 2019.

[2] G. U. Pribadi, "POTENSI WISATA KULINER KOTA MUNTILAN Studi Kasus: Wisata Kuliner di Koridor Jalan Veteran," Jurnal Arsitektur KOMPOSISI, vol. 12, no. 1, pp. 15-26, 2018.

[3] A. T. Akbar and E. Pangestuti, "Peran Kuliner Dalam Meningkatkan Citra Destinasi Pariwisata Taman Nasional Bromo Tengger Semeru," Jurnal Administrasi Bisnis, vol. 50, no. 1, pp. 153 159, 2017.

[4] Y. Kristiana, M. T. Suryadi, and S. R. Sunarya, "Eksplorasi Potensi Wisata Kuliner Untuk Pengembangan Pariwisata Di Kota Tangerang," Jurnal Khasanah Ilmu, vol. 9, no. 1, pp. 18-23, 2018.

[5] N. Rochmawati, Nailah, and I. Oktariadi, "Penelusuran Jejak Makanan Khas Semarang Sebagai Aset Inventarisasi dan Promosi Wisata Kuline Jawa Tengah," DIPO IPTEKS, I, vol. 1, no. 9, 
2013.

[6] R. Wibowo, "Analisis Perbandingan Karakteristik Yang Penting Bagi Wirausahawan Industri Kreatif Bidang Kuliner dan Non Kuliner Di Wilayah DKL Jakarta," Conference o Management and Behavioral Studies, pp. 284-292, 2016.

[7] A. Newman, "A Semantic Analysis of English and Hebrew Cooking Terms," vol. 37, 1975.

[8] D. Fitrisia, R. Sibarani, Mulyadi, and M. U. Ritonga, "Traditional food in the perspective of culinary linguistics," no. February, pp. 24-27, 2018.

[9] S. Rahayu, D. Pranita, and H. Rachmahani, "Kopi Sebagai Geo Product Untuk Geo Tourism : Konsep Sustainable Agricultural Practice,”vol. 5, no. 3, pp. 188-194, 2018. 